Acta vet. scand. $1984,25,1-9$.

From the Departments of Pathology, Microbiology and Immunology, and Husbandry and Genetics, Norwegian College of Veterinary Medicine, Oslo.

\title{
SWINE DYSENTERY: THE INFLUENCE OF DIETARY SELENIUM ON CLINICAL AND PATHOLOGICAL EFFECTS OF TREPONEMA HYODYSENTERIAE INFECTION
}

\author{
By \\ Jon Teige jr., Hans Jørgen Larsen and Sverre Tollersrud
}

TEIGE, JON JR., HANS JØRGEN LARSEN and SVERRE TOLLERSRUD: Swine dysentery: The influence of different levels of dietary selenium on clinical and pathological effects of Treponema hyodysenteriae infection. Acta vet. scand. 1984, 25, 1-9. - Twenty-four conventionally reared pigs divided into 4 groups were fed a basic ration deficient in selenium. The following daily supplement of selenium was given per pig; Group 1: none, group 2: $0.2 \mathrm{mg}$, group 3: $0.4 \mathrm{mg}$ and group 4: $0.8 \mathrm{mg}$. After 51 days all pigs were inoculated orally with a pure culture of Treponema hyodysenteriae, and subsequently observed for 26 days. Clinical signs of swine dysentery were seen in all 4 groups. Criteria such as morbidity rate, incubation time and weight gain showed that the non-supplemented pigs suffered more severely from swine dysentery than the supplemented ones. Best protection was found among the pigs given a daily supplement of $0.4 \mathrm{mg}$ selenium, whereas a supplement of $0.8 \mathrm{mg}$ had a negative influence on the resistance to swine dysentery. The results indicate that selenium plays a more complex role in mucosal defence mechanisms than hitherto anticipated.

swine dysentery; selenium supplementation;

Treponema hyodysenteriae.

The influence of vitamin $\mathbf{E}$ and selenium on the development of swine dysentery (SD) was studied in 4 experiments previously described (Teige et al. 1977, 1978, 1982). The last experiment revealed that selenium is more important than vitamin $E$ in this respect. The liver selenium values recorded in the supplemented groups were considered normal and sufficient to avoid vitamin $\mathbf{E}$ and selenium responsive diseases in pigs (Van Vleet et al. 1970, Simesen \& Pedersen 1975). Whether the selenium supplementation was optimal for the pigs' resistance to swine dysentery was, 
however, more uncertain. The present experiment was therefore performed to study the effect of different levels of selenium in pigs fed a basic ration with a constant level of vitamin $\mathbf{E}$.

\section{MATERIALS AND METHODS}

Experimental animals

Twenty-four conventionally reared pigs of both sexes were obtained from the same breeding stock as in previous experiments (Teige et al. 1982). The pigs had an average live weight of 17.3 $\mathrm{kg}$ when they were divided into 4 equal groups. The pigs were healthy until the time of inoculation. Experimental premises, procedures of feeding and other routines were as previously reported (Teige et al. 1982).

\section{Experimental diet}

The basic ration given to all pigs had with 2 exceptions the same composition as in the previous experiment (Teige et al. 1982). Firstly, the source of single cell protein was in this experiment made up of $80 \%$ Toprina (BP) and $20 \%$ Pruteen (ICI). This change was done due to shortage of Toprina on the market. Secondly, $50 \mathrm{mg}$ of $\alpha$-tocopherol was added per $\mathrm{kg}$ of the basic ration.

The selenium content of the basic ration was $0.009 \mathrm{mg}$ per $\mathrm{kg}$ (analysed at the Institutt for energiteknikk, Kjeller). The following daily supplements were given per pig in the different groups: group 1: none, group 2: $0.2 \mathrm{mg}$ selenium (given as sodium biselenite, $\mathrm{NaHSeO}_{3}$ ), group 3: $0.4 \mathrm{mg}$ and group 4:0.8 mg.

At the time of inoculation the pigs had been fed the experimental diets for 51 days.

\section{Haematological and biochemical tests}

Blood samples were taken from the anterior caval vein every second week during the experimental period to death or slaughter. Blood components were determined as previously described (Teige et al. 1982).

\section{Inoculation procedure}

The pigs were not fed for the last $12 \mathrm{~h}$ before given the contents of 5 petri dishes with a pure culture of $\mathrm{T}$. hyosenteriae on a trypticase soya agar (TSA) medium (Songer et al. 1976). The 
agar was given together with 21 of phosphate buffered saline. After $1 / 2 h$, when the pigs had consumed all the inoculum, they were fed their ordinary ration.

\section{Clinical and necropsy procedures}

Clinical examinations were the same as in the previous experiment (Teige et al. 1982). A faecal sample was collected on the day of infection and a rectal swab at day 7 and 14 after infection.

Necropsies were performed on 10 pigs, of which 7 died during the experiment and 3 still having diarrhoea when the experiment was concluded 26 days after infection. These 3 animals were euthanized by an intravenous injection of pentobarbital. Recovered and unaffected pigs were slaughtered. From all animals samples of liver, heart and skeletal muscles, colon and occasionally other organs were collected, fixed in formalin and embedded in paraffin. The sections were stained with haematotoxylin and eosin. Liver samples were also collected for selenium determination.

\section{Bacteriological procedures}

Faecal samples and swabs as well as samples collected at death or slaughter were examined according to the routine previously described (Teige et al. 1982).

\section{RESULTS}

\section{Haematological and biochemical findings}

Haematological and serum enzyme values recorded during the first 8 weeks of the experiment (i.e. up to 5 days after infection) showed no significant differences between groups. Average erythrocyte glutathione peroxidase (GSH-Px) values of group 1 collected at 2, 4 and 6 weeks after the start of the experiment, were 64, 39 and $35 \mathrm{u} / \mathrm{g}$ haemoglobin, respectively. No corresponding decrease in the GSH-Px values was seen among the other groups. The GSH-Px values and plasma $\alpha$-tocopherol level after 8 weeks are given in Table 1.

\section{Clinical observations}

The average daily weight gain up to the time of infection was $596 \mathrm{~g}, 613 \mathrm{~g}, 611 \mathrm{~g}$ and $611 \mathrm{~g}$ in groups $1,2,3$ and 4, respectively. Observations on incubation time, morbidity and mortality from 
Table 1. Erythrocyte glutathione peroxidase (GSH-Px) activities and plasma $\alpha$-tocopherol concentrations 8 weeks after the start of the experiment (5 days after infection). Liver selenium values at death or slaughter. Group mean $\pm \mathbf{s}$.

\begin{tabular}{lccc}
\hline Group & $\begin{array}{c}\text { GSH-Px } \\
(\mathrm{u} / \mathrm{g} \text { Hgb })\end{array}$ & $\begin{array}{c}\text { Plasma } \alpha- \\
\text { tocopherol } \\
(\mu \mathrm{g} / \mathrm{ml})\end{array}$ & $\begin{array}{c}\text { Liver selenium } \\
(\mu \mathrm{g} / \mathrm{g})\end{array}$ \\
\hline $\begin{array}{l}1 \\
2\end{array}$ & $17 \pm 5.1$ & $3.8 \pm 0.3$ & $0.05 \pm 0.01$ \\
$\left(\begin{array}{r}0.2 \mathrm{mg} \mathrm{Se}) \\
3\end{array}\right.$ & $112 \pm 7.1$ & $3.6 \pm 0.4$ & $0.47 \pm 0.03$ \\
$(0.4 \mathrm{mg} \mathrm{Se})$ & $108 \pm 23.1$ & $4.4 \pm 0.4$ & $0.53 \pm 0.03$ \\
4 & & $3.9 \pm 0.6$ & $0.62 \pm 0.06$ \\
\hline
\end{tabular}

SD, daily weight gain and occurrence of diarrhoea after infection are given in Tables 2 and 3. Pigs with the lowest weight gain in this period also had the poorest appetite. Blood stained diarrhoea appeared among pigs with SD in all groups. This clinical feature was most prevalent in group 1. Pigs recovering from SD had a reduced appetite and a somewhat unthrifty appearance during the period of diarrhoea. At the time of slaughter the only difference between the pigs having shown no clinical signs of SD and the recovered animals was a lower live weight of the latter. Pigs 4, 12 and 14 displayed a gaunt appearance and were still suffering from diarrhoea at the time of sacrifice. Observations on appetite and faecal appearance in these animals during the last days before sacrifice indicated that they were recovering from SD. The pigs which died (Table 2) lost their appetite pretty soon after the outbreak of the disease. They became unthrifty, very thin and recumbent, often with a bluish discoloration in extremis.

\section{Pathological findings}

The pathological findings are summarized in Table 2. The pigs dying from swine dysentery displayed a relative uniform picture at necropsy. There were some hyperemic changes in the mucosa of the stomach and the colonic lymph nodes were enlarged and hyperemic. The colonic wall was thicker than normal and the mucosa was covered by well-developed fibrinous membranes in the first half of the colon. In some of the pigs also the 
T a ble 2. Incubation periods, clinical observations, live weights and necropsy and bacteriological findings.

\begin{tabular}{|c|c|c|c|c|c|c|c|c|c|c|}
\hline Group & $\begin{array}{c}\text { Pig } \\
\text { num- } \\
\text { ber }\end{array}$ & $\begin{array}{l}\text { In- } \\
\text { cuba- } \\
\text { tion } \\
\text { period } \\
\text { (days) }\end{array}$ & $\begin{array}{c}\text { Days } \\
\text { of } \\
\text { diarr- } \\
\text { hoea }^{1}\end{array}$ & $\begin{array}{l}\text { Weight } \\
\text { at time } \\
\text { of ino- } \\
\text { culation } \\
(\mathrm{kg})\end{array}$ & $\begin{array}{l}\text { Weight } \\
\text { at death } \\
\text { or the } \\
\text { day of } \\
\text { slaughter } \\
\text { (kg) }\end{array}$ & $\begin{array}{l}\text { Lesions } \\
\text { indicat. } \\
\text { vit. E/Se } \\
\text { defici- } \\
\text { ency }^{2}\end{array}$ & \multicolumn{4}{|c|}{$\begin{array}{l}\text { Isolation of } \mathrm{T} \text {. hyodysenteriae, } \\
\text { days after infection }{ }^{3}\end{array}$} \\
\hline \multirow{6}{*}{1} & 1 & 6 & $5^{D}$ & 47.5 & 43 & (SMD) & +++ & & & \\
\hline & 2 & 7 & 3D & 48.5 & 45 & - & ++ & & & \\
\hline & 3 & 8 & 4D & 45.5 & 43 & SMD & ++ & & & \\
\hline & 4 & 13 & $14 \mathrm{NR}$ & 46.5 & 46 & (SMD) & 一 & +++ & ++ & +++ \\
\hline & 5 & 23 & 1 & 47.5 & 67 & (SMD) & 一 & - & + & - \\
\hline & 6 & $>26$ & 0 & 52 & 71 & (SMD) & 一 & - & - & - \\
\hline \multirow{6}{*}{$\begin{array}{c}2 \\
(0.2 \mathrm{mg} \mathrm{Se})\end{array}$} & 7 & 8 & 4D & 48 & 44 & - & ++ & & & \\
\hline & 8 & 8 & 8 & 51.5 & 66.5 & - & ++ & +++ & - & - \\
\hline & 9 & 9 & 7 & 50.5 & 62 & (SMD) & +++ & - & - & - \\
\hline & 10 & 14 & 8 & 50 & 62 & (SMD) & + & +++ & + & - \\
\hline & 11 & 16 & 5 & 47 & 62 & - & 一 & - & +++ & - \\
\hline & 12 & 20 & $7 \mathrm{NR}$ & 45.5 & 54 & - & 一 & + & +++ & ++ \\
\hline \multirow{6}{*}{$\begin{array}{c}3 \\
(0.4 \mathrm{mg} \mathrm{Se})\end{array}$} & 13 & 9 & 1 & 50 & 69 & - & - & - & + & - \\
\hline & 14 & 14 & $13 N R$ & 46 & 48 & (SMD) & - & +++ & +++ & $+t+$ \\
\hline & 15 & $>26$ & 0 & 49.5 & 67 & - & - & - & - & - \\
\hline & 16 & $>26$ & 0 & 48 & 66 & - & - & - & - & - \\
\hline & 17 & $>26$ & 0 & 52 & 71 & (SMD) & + & 一 & - & - \\
\hline & 18 & $>26$ & 0 & 46 & 65 & - & +++ & - & - & - \\
\hline \multirow{6}{*}{$\begin{array}{c}4 \\
(0.8 \mathrm{mg} \mathrm{Se})\end{array}$} & 19 & 6 & $4 D$ & 50.5 & 44.5 & SMD & +++ & & & \\
\hline & 20 & 7 & $6 \mathrm{D}$ & 46.5 & 42 & SMD & +++ & & & \\
\hline & 21 & 7 & 9 & 46.5 & 61 & SMD & ++ & - & - & - \\
\hline & 22 & 10 & $7 \mathrm{D}$ & 48.5 & 47.5 & SMD & +++ & +++ & & \\
\hline & 23 & $>26$ & 0 & 48 & 68 & 一 & - & - & - & - \\
\hline & 24 & $>26$ & 0 & 51.5 & 71 & (SMD) & - & - & - & - \\
\hline $\begin{array}{l}\text { 1) D: } \\
\text { NR: }\end{array}$ & \multirow{2}{*}{\multicolumn{10}{|c|}{$\begin{array}{l}\text { Died of swine dysentery. } \\
\text { Not recovered at the end of } \\
\text { experiment. } \\
\text { Skeletal muscle degeneration. } \\
\text { Very small lesions. }\end{array}$}} \\
\hline $\begin{array}{l}\text { 2) SMD : } \\
\text { (SMD) : }\end{array}$ & & & & & & & & & & \\
\hline
\end{tabular}

second half contained similar membranes. The colonic contents were thin and often haemorrhagic. The histological examination revealed lesions in accordance with a previous report (Teige 1978). The pigs not recovered at the time of sacrifice (Table 2) had thin, watery colonic contents. The mucosa was somewhat swollen and moderately hyperemic. There were, however, no pseudomembranes in the colon of these animals. The gastro- 
Table 3. Incubation periods, morbidity and mortality of SD, average daily weight gain and occurrence of diarrhoea.

\begin{tabular}{|c|c|c|c|c|c|c|}
\hline $\begin{array}{l}\text { Group } \\
\text { (Daily Se- } \\
\text { supple- } \\
\text { mentation) }\end{array}$ & $\begin{array}{l}\text { Incubation } \\
\text { period } \\
\text { (days) }\end{array}$ & $\begin{array}{c}\text { SD- } \\
\text { morbidity } \\
\text { (nos. of } \\
\text { pigs) }\end{array}$ & $\begin{array}{c}\text { SD- } \\
\text { mor- } \\
\text { tality } \\
\text { (nos. of } \\
\text { pigs) }\end{array}$ & $\begin{array}{c}\text { Average } \\
\text { daily } \\
\text { weight gain } \\
\text { after in- } \\
\text { fection (g) }\end{array}$ & $\begin{array}{c}\text { Days of } \\
\text { observa- } \\
\text { tion after } \\
\text { infection }\end{array}$ & $\begin{array}{c}\text { Days of } \\
\text { diarrhoea }\end{array}$ \\
\hline $\begin{array}{c}1 \\
\text { (none) }\end{array}$ & $>13.8$ & 5 & 3 & 255 & 109 & $27(25 \%)$ \\
\hline $\begin{array}{l}\quad 2 \\
(0.2 \mathrm{mg} \mathrm{Se})\end{array}$ & 12.5 & 6 & 1 & 411 & 142 & $39(27 \%)$ \\
\hline $\begin{array}{l}3 \\
(0.4 \mathrm{mg} \mathrm{Se})\end{array}$ & $>21.2$ & 2 & 0 & 606 & 156 & $14(9 \%)$ \\
\hline $\begin{array}{l}\quad 4 \\
(0.8 \mathrm{mg} \mathrm{Se})\end{array}$ & $>13.7$ & 4 & 3 & 370 & 118 & $26(22 \%)$ \\
\hline
\end{tabular}

intestinal tract of the remaining pigs showed a normal picture. The histological examination further revealed hyaline degeneration in the skeletal muscles of the pigs in group 4 (Table 2). Similar lesions were only slightly visible among the other animals.

\section{Liver selenium}

The contents of selenium in the liver are recorded in Table 1.

\section{Bacteriological findings}

Swabs collected on the day of inoculation showed no occurrence of $T$. hyodysenteriae. Demonstration of this bacterium in swabs and mucosal scrapings after infection is given in Table 2. At the time of sacrifice isolation of $T$. hyodysenteriae was positive only in 3 nonrecovered pigs. Salmonella spp. were not isolated.

\section{DISCUSSION}

Inoculation with $\mathrm{T}$. hyodysenteriae provoked outbreaks of swine dysentery in all groups of pigs. The GSH-Px values and levels of selenium in the liver revealed a state of deficiency of this element in the pigs of group 1. In the other animals, liver selenium was in accordance with their supplements and above the level found in pigs avoiding vitamin $\mathbf{E}$ and selenium responsive diseases (Van Vleet et al. 1970, Simesen \& Pedersen 1975). The strongest attack from SD was seen among the pigs in group 
1 , where 3 died from the disease. The lowest average daily weight gain after infection was also recorded in this group. There was, however, no significant difference between groups 1 and 4, although a somewhat higher weight gain in the post infection period was observed in the latter group. With emphasis on the mortality rate, but especially on the morbidity and recovery rates, the results further indicate that resistance to SD was better in group 2 than in group 1 and 4 . The lowest morbidity and mortality rates were found in group 3 , where only 1 pig was seriously affected. It may be concluded that the selenium level given in group 3 was the optimal level in the present experiment $(0.4 \mathrm{mg}$ Se per pig per day).

The inoculum given was highly infective according to the results recorded in groups 1,2 and 4 . Another implication of the observations in group 3 may therefore be that a proper dose of selenium seems to improve the resistance to SD. The detrimental effect of the selenium level in group 4 was unexpected. As the individual reaction to an experimental infection can be variable, further experiments are needed to comfirm this observation. The liver selenium values recorded in this group were, however, on the same level as recently demonstrated in Norwegian slaughter pigs (Frøslie, personal communication 1983). As no harmful effect of selenium on pig performance has been observed in pigs on a dietary level of $2.2 \mathrm{mg}$ selenium per $\mathrm{kg}$ feed and with liver selenium values of $1.6 \mathrm{mg}$ per $\mathrm{kg}$ (Moksnes et al. 1982), it seems unlikely that the results should be due to any toxic effect of this element. Another observation in group 4 was skeletal muscle degeneration in some pigs. Both clinical records and pathological findings indicated that the same animals had been seriously affected by SD. As the dietary level of selenium and vitamin $\mathbf{E}$ was more than sufficient to avoid nutrional muscular degeneration, it may be suggested that the degenerative lesions have developed secondary to the pigs' enteritic disorder.

Observations indicate that neither epithelial attachment nor penetration of $T$. hyodysenteriae seems to play any significant role in SD-pathogenesis (Teige et al. 1981). Defence mechanisms in the colonic mucosa or the primary defence seems therefore to be important for the resistance to this intestinal disorder. The role of selenium in this respect may include different parts of the body's defence against microbial agents. The element will enhance humoral and cellular immunity and stimulate phago- 
cytic and bacterial activity (Spallholz 1981). The same author further proposes that an increased glutathione peroxidase activity as well as other specific selenium functions in lymphocytes and macrophages are responsible for the immunoenhancement attributed to supplements of this element. As none of the pigs in the present and previous experiment (Teige et al. 1982) had been infected with $T$. hyodysenteriae prior to inoculation, the effect of selenium on SD-resistance may therefore primarily be due to stimulation of the non-specific immunity in the colonic mucosa. Exposure to T. hyodysenteriae causes cellular and humoral immune response to this bacterium in pigs (Joens et al. 1979, Jenkins \& Klesius 1981). It is suggested that enhancement of this response by selenium supplementation may improve the recovery rate from SD and also the resistance to reexposure from $T$. hyodysenteria. Regarding non-specific immunity of the gut it has previously been suggested that degenerative changes in the colonic epithelium of vitamin $\mathrm{E}$ and selenium deficient pigs may imply weaker primary defence (Teige \& Nafstad 1978). Further investigations are in progress in order to elucidate the importance of other defence mechanisms to SD-resistance.

\section{AGKNOWLEDGEMENTS}

We would like to thank Dr. J. U. Skaare of the Norwegian College of Veterinary Medicine, Oslo, for performing the analyses for plasma $\alpha$-tocopherol and the Department of Toxicology, National Veterinary Institute, Oslo, for performing the analyses for selenium in liver.

\section{REFERENCES}

Jenkins, E. M. \& P. L. Klesius: Lymphocyte stimulation in swine dysentery. Vet. Immunol. Immunpathol. 1981, 2, 19-26.

Joens, L. A., D. L. Harris \& D. H. Baum: Immunity to swine dysentery in recovered pigs. Amer. J. vet. Res. 1979, 40, 1352-1354.

Moksnes, K., S. Tollersrud \& H. J. Larsen: Influence of dietary sodium selenite on tissue selenium levels of growing pigs. Acta vet. scand. $1982,23,361-367$.

Simesen, M. G. \& K. B. Pedersen: Selenium determinations in Danish swine affected with hepatosis dietetica. Acta vet. scand. 1975, $16,137-139$.

Songer, J. G., J. M. Kinyon \& D. L. Harris: Selective medium for isolation of Treponema hyodysenteriae. J. clin. Microbiol. 1976, 4, $57-60$.

Spallholz, J. E.: Anti-inflammatory, immunologic and carcinostatic attributes of selenium in experimental animals. Adv. exp. Med. Biol. 1981, 135, 43-62.

Teige, J.: Influence of diet on experimental swine dysentery 3. Pathological changes. Acta vet. scand. 1978, 19, 506-519. 
Teige, J., T. Landsverk, A. Lund \& H. J. Larsen: Swine dysentery: A scanning electron microscopic investigation. Acta vet. scand. 1981, 22, 218-225.

Teige, J.\& P.H.J. Nafstad: Ultrastructure of colonic epithelial cells in vitamin $\mathrm{E}$ and selenium deficient pigs. Acta vet. scand. 1978, 19, $549-560$.

Teige, J., K. Nordstoga \& J. Aursj申: Influence of diet on experimental swine dysentery 1 . Effects of a vitamin $E$ and selenium deficient diet supplemented with $6.8 \%$ cod liver oil. Acta vet. scand. 1977, 18, 384-396.

Teige, J., F. Saxegaard \& A. Fr $\varnothing$ slie: Influence of diet on experimental swine dysentery 2 . Effects of a vitamin $\mathrm{E}$ and selenium deficient diet supplemented with $3 \%$ cod liver oil, vitamin $\mathrm{E}$ or selenium. Acta vet. scand. $1978,19,133-146$.

Teige, J., A. Lund \& H. J. Larsen: Swine dysentery: The influence of dietary vitamin $\mathrm{E}$ and selenium on the clinical and pathological effects of Treponema hyodysenteriae infection in pigs. Res. Vet. Sci. 1982, 32, 95-100.

Van Vleet, J. F., W. Carlton \& H. J. Olander: Hepatosis dietetica and Mulberry heart disease associated with selenium deficiency 'in Indiana swine. J. Amer. vet. med. Ass. 1970, 157, 1208-1219.

\section{SAMMENDRAG}

Svinedysenteri: Virkningen av forskjellige nivåer av selen $i$ dietten på de kliniske og patologiske utslag av infeksjon med Treponema hyodysenteriae.

Tjuefire vanlig oppdrettede griser ble delt i fire grupper og gitt et selenfattig grunnfór. Følgende daglige tilskudd av selen ble gitt til hver gris: gruppe 1: 0, gruppe 2: $0.2 \mathrm{mg}$, gruppe 3: $0.4 \mathrm{mg}$ og gruppe 4: $0.8 \mathrm{mg}$. Etterat grisene var blitt fóret med de forskjellige diettene $\mathrm{i}$ 51 dager ble de podet med en renkultur av $T$. hyodysenteriae pr. os. og deretter observert i 26 dager. Kliniske symptomer på svinedysenteri ble sett $i$ alle fire gruppene. Registreringer vedrørende morbiditet, inkubasjonstider og tilvekst viste at grisene uten tilskudd av selen hadde en mer alvorlig form av svinedysenteri enn de som fikk tilskudd. Den beste beskyttelsen mot infeksjon med $T$. hyodysenteriae ble sett hos griser med et daglig tilskudd på $0.4 \mathrm{mg}$ selen. Et daglig tilskudd på $0.8 \mathrm{mg}$ selen hadde en negativ virkning på resistensen mot svinedysenteri. Disse resultater kan derfor tyde på at selen spiller en mer kompleks rolle i tarmslimhinnens forsvarsmekanismer enn man hittil har vært klar over.

(Received November 25, 1983).

Reprints may be requested from: Jon Teige jr., Department of Pathology, Norwegian College of Veterinary Medicine, P. O. Box 8146 Dep, 0033 Oslo, Norway. 